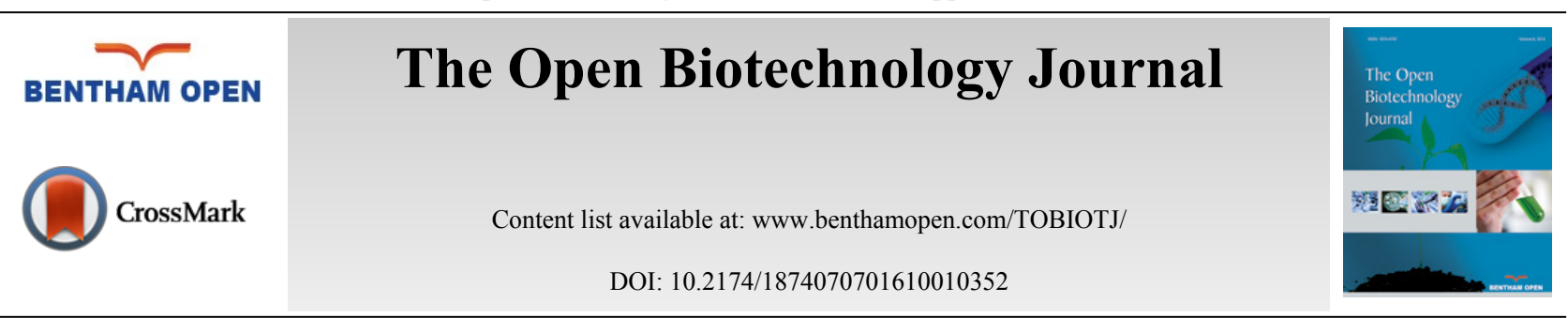

REVIEW ARTICLE

\title{
Heavy Metals in Sewage Treated Effluents: Pollution and Microbial Bioremediation from Arid Regions
}

\author{
Salma K. Al-Musharafi \\ Department of Applied Biotechnology, Sur College of Applied Sciences, Ministry of Higher Education, Sur, Sultanate of \\ Oman
}

\begin{abstract}
Not all heavy metals are toxic. Some at lower concentrations are essential to the physiological status of the organism. Under certain conditions, induced toxicity occurs when the heavy metals are in the form of cations which tends to bind to certain biomolecules, thus becoming toxic to organisms. In many industries, toxic heavy metals such as $\mathrm{As}, \mathrm{Cd}, \mathrm{Cr}, \mathrm{Cu}, \mathrm{Hg}, \mathrm{Pb}$ and $\mathrm{Zn}$, are released mainly in sewage effluents causing major environmental pollution. Several of the heavy metal contaminations resulted from industrial wastes, along with the mining and burning of fossil fuels, leading to water and soil contamination which causes serious health problems. Rapid population growth plus a steady increase in agriculture and industry are the main cause of environmental pollution. The most common sources of heavy metals are fuel combustion, mining, metallurgical industries, corrosion and waste disposal which infiltrates the soil and underground water. When present at certain levels in the human, metals can cause certain diseases. Most of conventional technologies are inefficient to remove heavy metal contaminants. Microbial bioremediation is a potential method for the removal of heavy metal pollution in sewage effluents before being discharged into the environment. However, further research is needed for isolation and identification of microbes resistant to heavy metals. Industrial regulatory standards must be established to regulate the spread of non-essential metals in the environment. The regulations must be rigidly enforced. The rest of the essential metals must also be regulated since an increase over the physiological limit can also be harmful.
\end{abstract}

Keywords: Arid regions, Heavy metals, Microbial bioremediation, Pollution, Sewage, Toxicity.

\section{INTRODUCTION}

Heavy metals are generally classified into three groups: basic metals, metalloids and transition metals. The metallic group has properties in atomic mass less than 20 [1]. The majority of heavy metals are transition metals. Whether metalloids or light metals, their toxicity varies according to the metal oxidation state and the concentration. Some heavy metals at specific oxidation state are trace elements, while in another oxidation state they become highly toxic. Therefore, not all heavy metals are toxic to organisms [2]. Some heavy metals at a lower concentration are essential elements and become toxic with concentration increase [3]. However, there are some heavy metals, such as $\mathrm{Pb}$ and $\mathrm{Hg}$, which are highly toxic even at a low concentration. Toxicity of some heavy metals exists when they are in a specific form. For example, in soluble form, some heavy metals become toxic, affecting the physiologic state of organisms. The toxicity occurs when heavy metals are in the form of cations which enable them to bind to proteins and other biomolecules. Therefore, accumulation of non-essential heavy metal in organism tissue was used as bioindicators of environmental pollution [4].

Most heavy metals are used in light and heavy industries. In manufacturing, many of the heavy metals are released with sewage effluents causing environmental pollution. Since they cannot be destroyed, they accumulate in the environment affecting organisms, leading to toxicity and illnesses with diarrhea, vomiting, abdominal pain, nausea, heart problems and anemia, while some heavy metals are known mutagens causing cancer $[5,6]$.

\footnotetext{
* Address correspondence to this author at the Department of Applied Sciences, Sur College of Applied Sciences, Ministry of Higher Education, Sur, Sultanate of Oman; Tel: 25544150; E-mail: salma.sur@cas.edu.om
} 
Many of the industrialized nations have serious environmental problems and challenges in controlling, heavy metal pollution along with health related issues, with only partial success avoiding heavy metal pollution in the environment. This is a major problem in the developing countries [7, 8]. Several major sources of heavy metal contamination which include consumer use of heavy metals, industrial waste, mining, and burning of fossil fuels leads to accumulation in soil, sediments, water and the food chain $[9,10]$.

To minimize heavy metal pollution, it is essential to have an effective monitoring system controlling industrial sewage effluents before they are released to the environment [11].

Heavy metal toxicity has been spreading rapidly in association with industrialization and increased release of pollutants to terrestrial and aquatic environments, causing threats to public health and has become common in many parts of the world [11 - 16]. Heavy metal pollution was reported to contaminate domestic animals, crops, and affect humans when consumed [3, 4, 17 - 22].

Several studies reported that heavy metal pollution was one of the main factors in declining populations in different habitats [17, 21]. It is well established that heavy metals lead to chronic diseases when excessively accumulated in organisms [23, 24]. A gradual bioaccumulation will ultimately become fatal [3].

So far, there are no sufficient technologies to detoxify heavy metal pollutants. The objectives of this article are to provide report on the economic importance of the heavy metals and type of heavy metals in relation to its adverse effects on environment and public health. Also, this paper will give an overview on microbial bioremediation of heavy metals in contaminated effluents.

\section{GLOBAL METAL RESOURCES}

Minerals and metals have played an important role in economy throughout the world. In general, minerals and metals are used in roads, general construction, and industries involving electronic devices, such as computers, telephones, semiconductors and other electric devices. Mineral resources are classified into two groups, metallic and non-metallic. The non-metallic minerals include dimension stone, gravel, uranium, gypsum and halite. The metallic minerals include aluminum, chromium, copper, gold, iron, lead, nickel, silver, tin, and zinc. The most abundant metal is aluminum followed by iron, titanium, chromium, zinc, copper, silver, platinum, gold and uranium [25]. Based on biological importance heavy metals are classified into essential metals with many biological functions $(\mathrm{Ca}, \mathrm{Co}, \mathrm{Cu}, \mathrm{Fe}$, $\mathrm{K}, \mathrm{Mg}, \mathrm{Mn}, \mathrm{Mo}, \mathrm{Na}, \mathrm{Ni}, \mathrm{V}, \mathrm{W}, \mathrm{Zn}$ ), toxic metals (Ag, Al, Au, Cd, Hg, Pb, Sn, Ti), none essential nontoxic metals (Cs, $\mathrm{Rb}, \mathrm{Sr}, \mathrm{T}$ ) and metalloids (As, Ge, Sb, Se) [2]. Economically, metals are classified into four categories: industrial, precious, critical and additional metals [26] (Table 1).

Table 1. Economical classification of metals [26].

\begin{tabular}{|c|c|c|c|c|c|c|c|c|}
\hline Industrial & Precious & \multicolumn{3}{|c|}{ Critical } & \multicolumn{4}{c|}{ Additional } \\
\hline $\mathrm{Al}$ & $\mathrm{Ag}$ & $\mathrm{Be}$ & $\mathrm{Pd}$ & $\mathrm{Ce}$ & $\mathrm{Ho}$ & $\mathrm{Li}$ & $\mathrm{Cr}$ & $\mathrm{Te}$ \\
\hline $\mathrm{Fe}$ & $\mathrm{Pt}$ & $\mathrm{Mg}$ & $\mathrm{In}$ & $\mathrm{Pr}$ & $\mathrm{Er}$ & $\mathrm{B}$ & $\mathrm{Mn}$ & $\mathrm{Ba}$ \\
\hline $\mathrm{Cu}$ & $\mathrm{Au}$ & $\mathrm{Co}$ & $\mathrm{Sb}$ & $\mathrm{Nd}$ & $\mathrm{Tm}$ & $\mathrm{Na}$ & $\mathrm{Ni}$ & $\mathrm{Re}$ \\
\hline $\mathrm{Zn}$ & & $\mathrm{Ga}$ & $\mathrm{Ta}$ & $\mathrm{Sm}$ & $\mathrm{Yb}$ & $\mathrm{Si}$ & $\mathrm{As}$ & $\mathrm{Tl}$ \\
\hline $\mathrm{Sn}$ & & $\mathrm{Ge}$ & $\mathrm{W}$ & $\mathrm{Eu}$ & $\mathrm{Lu}$ & $\mathrm{K}$ & $\mathrm{Sr}$ & $\mathrm{Bi}$ \\
\hline $\mathrm{Hg}$ & & $\mathrm{Nb}$ & $\mathrm{Os}$ & $\mathrm{Gd}$ & & $\mathrm{Ca}$ & $\mathrm{Y}$ & \\
\hline $\mathrm{Pb}$ & & $\mathrm{Ru}$ & $\mathrm{Ir}$ & $\mathrm{Tb}$ & & $\mathrm{Ti}$ & $\mathrm{Zr}$ & \\
\hline & & $\mathrm{Rh}$ & $\mathrm{La}$ & $\mathrm{Dy}$ & & $\mathrm{V}$ & $\mathrm{Mo}$ & $\mathrm{Mo}$ \\
\hline
\end{tabular}

Metals and mineral resources are usually not renewable. Those minerals are not distributed evenly throughout the world. Some countries are mineral-rich while others are mineral-poor [25]. The share of the global metal industry varies among the producing countries with China taking the lead with a share of $27 \%$ followed by Australia (4\%), Russia, USA, and Chile (3\%) each, Canada (2\%), while Brazil, DRC, India, Japan, Kazakhstan, Mexico, Peru, South Africa, Rwanda and Turkey (1\%) [26]. The rest of the countries fall below those values. However, China has been seriously environmentally impacted with the rapid modernization in all aspects of industries, mainly depending on steel and other metals. For example, red alert of severe air pollution was issued in ten major cities in China in December 2015. Such magnitude of air pollution affecting a wide area due to industrialization rarely occurs. The smog pollution affected 30 other smaller cities, including Beijing. Pollution was caused by many industry sectors throughout China [7]. The Organization for Economic Co-operation and Development (OECD) [27] reported that the highest mortality rate from 
outdoor pollution between 2005-2010 was China followed by India with an estimated cost of USD 3.5 trillion a year. Number of mortalities in outdoor air pollution exceeded the rest of the world (GBD 2014) [28]. The Pearl River delta in south China and the Yangtze delta in east China were the most polluted regions due to industries and mining. The two regions are heavily polluted with arsenic, cadmium, lead and mercury. It was reported that about 12 million tons per year of food produced in China is contaminated with toxic heavy metals. China has introduced soil-heavy-metalsremediation project with the estimated cost of more than 4 billion USD [8]. These conditions have led China to environmental disasters coupled with serious public health related issues which may also heavily impact their economy.

There is a major global concern on the management of metals in industry and recycling. The increased demand for metals will lead to significant global deficiency, specifically the platinum group [29]. Recycling of metals is therefore a wise practice. With the current technologies and challenges, it was reported that the current recycling process of metals does not meet the demand of most metals used in various industries [26]. Only 1\% of most metals mentioned in Table 1 can be recycled as indicated in Table 2. Most of the low-recycled metals are involved in many high-tech industries such solar PV, microchips, and consumer electronics. For example, sixty elements may be involved in manufacturing circuit boards and microprocessors, some of which are impossible to recycle due to technical limits or as a result of oxidation in the smelting slag [29]. If the current situation of metal loss continues, most of the current technologies will be facing a tremendous shortage. On the other hand, it was reported that it is not likely that there will be a complete depletion of useful mineral resources. However, he stressed that if the current economical supply deposits are depleted, and the cost will increase dramatically and the concentration factor will also increase [25].

Table 2. Metal recycling percentages [29].

\begin{tabular}{|c|c|c|c|c|c|c|c|c|}
\hline \multicolumn{4}{|c|}{$<1 \%$} & \multirow{2}{*}{$\begin{array}{c}\mathbf{1 - 1 0 \%} \\
\mathrm{Hg} \\
\end{array}$} & \multirow{2}{*}{$\frac{>10-25 \%}{\mathrm{Ru}}$} & \multirow{2}{*}{$\frac{\mathbf{2 5 - 5 0 \%}}{\mathrm{Mg}}$} & \multicolumn{2}{|c|}{$>50 \%$} \\
\hline $\mathrm{Be}$ & $\mathrm{Pr}$ & $\mathrm{Tm}$ & $\mathrm{Zr}$ & & & & $\mathrm{Al}$ & $\mathrm{Co}$ \\
\hline $\mathrm{Ga}$ & $\mathrm{Nd}$ & $\mathrm{Yb}$ & $\mathrm{Ba}$ & $\mathrm{Sb}$ & $\mathrm{W}$ & $\mathrm{Ir}$ & $\mathrm{Fe}$ & $\mathrm{Nb}$ \\
\hline $\mathrm{Ge}$ & $\mathrm{Sm}$ & $\mathrm{Lu}$ & $\mathrm{Tl}$ & & & Mo & $\mathrm{Cu}$ & $\mathrm{Rh}$ \\
\hline In & $\mathrm{Eu}$ & $\mathrm{Li}$ & $\mathrm{Ti}$ & & & & $\mathrm{Zn}$ & $\mathrm{Pd}$ \\
\hline $\mathrm{Ta}$ & $\mathrm{Gd}$ & $\mathrm{B}$ & & & & & Sn & $\mathrm{Ti}$ \\
\hline $\mathrm{Te}$ & $\mathrm{Tb}$ & $\mathrm{V}$ & & & & & $\mathrm{Pb}$ & $\mathrm{Cr}$ \\
\hline Os & Dy & As & & & & & $\mathrm{Ag}$ & $\mathrm{Mn}$ \\
\hline $\mathrm{La}$ & Ho & $\mathrm{Sr}$ & & & & & $\mathrm{Pt}$ & $\mathrm{Ni}$ \\
\hline $\mathrm{Ce}$ & $\mathrm{Er}$ & $\mathrm{Y}$ & & & & & $\mathrm{Au}$ & $\mathrm{Re}$ \\
\hline
\end{tabular}

The most recycled metals are aluminum and steel [30]. The plentiful metals such as $\mathrm{Al}, \mathrm{Cu}, \mathrm{Ni}, \mathrm{Pb}$, and $\mathrm{Zn}$ with recycling rates of more than $50 \%$ due to their existence in pure forms (Table 2). The rest of the metals are lost, causing accumulation in the environment. The other precious metals are at low-recovery rate. Some of unrecovered metals are highly toxic to organisms [29].

Heavy metal pollution should be dealt jointly in a global effort by setting up international regulatory standards to minimize its impact on the environment which directly affects public health. Several international organizations have established regulatory heavy metals standards. However, these standards are not unified [31 - 37] and have deficiencies in many elements mentioned in Tables $\mathbf{1}$ and 2. Also, most of the metals are not recycled, leading to their accumulation in the environment causing pollution [29].

\section{Environmental Pollution \& Health}

Due to excessive industrialization accompanied by rapid global population growth and increase in agricultural practices, heavy metals $\mathrm{As}, \mathrm{Cd}, \mathrm{Cr}, \mathrm{Cu}, \mathrm{Hg}, \mathrm{Pb}$, and $\mathrm{Zn}$ are the most common environmental pollutants [1, 38]. Generally, the sources of heavy metal pollution are mining, smelting, metallurgical industries, corrosion, waste disposal, fossil fuel combustion agriculture and forestry [5, 38 - 48]. As a result, the contaminants spread through air and accumulate in soil infiltrating underground water. Consequently, this causes severe ecosystem damages, entering the food chain through contaminated soil and water [1, 3, 4, $11-15,49,50]$. More than ten million polluted sites were reported across the globe. Most of the polluted sites are contaminated with heavy metals and metalloids causing more than ten billion USD annually [1]. It was reported in 2009, Belgium has the maximum heavy metal pollution in Europe, followed by Greece. In 2012, Poland exceeded Belgium followed by Romania, while Greece decreased to lower levels [51].

Almost all mercury emission is from fossil fuel (46\%) combustion, followed by gold production (24\%), metal and 
cement production (10\% each) and waste incineration $(6 \%)$. The major source of mercury air emissions from the US industrial sources and power plants is estimated at about more than half of anthropogenic emission. About 33 tons of mercury are released from power plants annually [52].

In addition to natural process, as anthropogenic activities are the main sources of pollution, which include fossil fuel combustion, smelting, waste disposal, mining, farming and corrosion [1]. Some of the toxic metals ( $\mathrm{As}, \mathrm{Cd}, \mathrm{Hg}, \mathrm{Pb}$, and $\mathrm{Se}$ ) residence time in the atmosphere, land, ocean and sediments differs significantly. In general, metal residence time in sediments ranges between year $90.8 \times 10^{6}$ for $\mathrm{Hg}$ to $99.8 \times 10^{6}$ for $\mathrm{As}$ and $\mathrm{Cd}$, while the least residence time in atmosphere ranges between years. $1.0 \times 10^{-1}$ for $\mathrm{Hg}$ to $3.0 \times 10^{-2} \mathrm{As}$ and $\mathrm{Se}$ [53].

Toxicity of heavy metals in human health and various organisms has been reported by many investigators (Table $\mathbf{3}$ ). The effects range from low to severe cases with degenerative effects by interfering with specific cellular metabolic processes reducing natural detoxification mechanisms. For example, lead, mercury, and cadmium prevent glutathione Stransferase from liver peroxidase activity [43]. Other heavy metals mimic essential elements reducing co-factor activity at molecular level of cellular metabolism. Several factors are involved in heavy metal toxicity. These factors include route of exposure, type of metal and age.

Table 3. Metal sources relative to toxicities and human diseases.

\begin{tabular}{|c|c|c|c|}
\hline Metal & Source & Effect in humans & References \\
\hline Aluminum & $\begin{array}{l}\text { Abundant metal in the earth's crust, found in food and } \\
\text { water, cosmetics }\end{array}$ & Alzheimer, Parkinson, senility, prehensile dementia, & {$[39,42,44,54]$} \\
\hline Arsenic & $\begin{array}{l}\text { Natural existence in inorganic and organic forms. } \\
\text { Organic form commonly found in seafood, pesticides, } \\
\text { coal combustion, metal smelters, mine leachate, wood } \\
\text { preservative, tobacco smoke, cosmetics }\end{array}$ & $\begin{array}{l}\text { Non-essential element, trivalent arsenic is more toxic than } \\
\text { pentavalent, cumulative poison, carcinogen, abdominal pain, } \\
\text { black foot disease, hepatoxicity, birth defects, cardiovascular } \\
\text { mortality, gastrointestinal damage, vomiting and diarrhea }\end{array}$ & {$\left[\begin{array}{c}38-40,54,67 \\
68]\end{array}\right.$} \\
\hline Beryllium & $\begin{array}{c}\text { Volcanic dust, coal, rock, soil aerospace industries, } \\
\text { ceramic manufacturing, X-ray transmission windows, } \\
\text { nuclear reactor, navigational systems, audio } \\
\text { components, fluorescent lamps, computers components, } \\
\text { dental labs, microwave devices, telecommunication } \\
\text { devices, cosmetics }\end{array}$ & $\begin{array}{l}\text { Non-essential element, carcinogen, chronic beryllium disease } \\
\text { (CBD); lungs and respiratory diseases, skin diseases. } \\
\text { conjunctivitis, rhinitis, infidelity of DNA replication }\end{array}$ & {$[54,69-72]$} \\
\hline Cadmium & $\begin{array}{l}\text { Marine environment, mining, electroplating industry, } \\
\text { PVC industry, Ni-Cd Batteries, plastics, paints, } \\
\text { fertilizers, pesticides, anticorrosive agent, voltaic } \\
\text { devices, TV industries, cosmetics, Textiles }\end{array}$ & $\begin{array}{l}\text { Non-essential element, highly toxic \& fatal, DNA damage, } \\
\text { carcinogen, embryotoxic, placental abnormalities, } \\
\text { nephrotoxicity, hypertension, hepatoxicity, renal dysfunction, } \\
\text { pancreas toxicity, placental abnormalities, apoptosis in testis, } \\
\text { bones softening, blood pressure, osteoporosis }\end{array}$ & $\begin{array}{l}{[5,6,38,43} \\
46,48,54,67 \\
73,74,38]\end{array}$ \\
\hline Chromium & $\begin{array}{l}\text { Element of earth crust, soil, water, lather and tanning } \\
\text { industries, paper and pulp manufacturing, mineral } \\
\text { resources, mines, cosmetics }\end{array}$ & $\begin{array}{l}\text { Essential element (chromium III), lung damage, hepatoxicity, } \\
\text { carcinogen, renal tubular necrosis, skin and stomach } \\
\text { ulceration, hematological toxicity, weakened immune system, } \\
\text { central nervous system }\end{array}$ & {$[54,67,68,74]$} \\
\hline Cobalt & $\begin{array}{c}\text { Alloy manufacture, corrosion resistant alloys, petroleum } \\
\text { and chemical industries, paint drying agent, medical } \\
\text { treatment, food preservation, ceramic and porcelain } \\
\text { production, nuclear power plants }\end{array}$ & $\begin{array}{l}\text { Essential element, weakening human health, reactive oxygen } \\
\text { species }\end{array}$ & {$[38,75]$} \\
\hline Copper & $\begin{array}{c}\text { Utensil manufacturing, pipes, bronze, electrical wires, } \\
\text { mining, chemical industry, pesticide production, metal } \\
\text { piping }\end{array}$ & $\begin{array}{l}\text { Essential element, DNA damage and carcinogen, } \\
\text { embryotoxic, stomach and kidney damages, diarrhea, } \\
\text { vomiting, loss of strength }\end{array}$ & {$[48,54,68,74]$} \\
\hline Iron & Most common metal, drinking water, cosmetics & $\begin{array}{c}\text { Essential element, affecting melanin and causing grey or } \\
\text { bronze skin color pigmentation, kdney, hepatoxicity, heart } \\
\text { failure, joint diseases, acute toxicity to newborn babies and } \\
\text { young children }\end{array}$ & {$[38,39,41,45]$} \\
\hline Lead & $\begin{array}{c}\text { Painted items with led paint, water pipes, children toys } \\
\text { and some cosmetic, industrial discharges, electronic } \\
\text { solders, sewage effluent, fossil fuels burning, roofing } \\
\text { industry, ceramic industry, battery manufacturing, } \\
\text { textiles }\end{array}$ & $\begin{array}{l}\text { Non-essential element, DNA damage, carcinogen, } \\
\text { embryotoxic, most frequent toxic metal, metabolic toxicity, } \\
\text { joint disease, kidney toxicity, reproductive system, abnormal } \\
\text { circulatory system, central nervous system and } \\
\text { gastrointestinal tract, affects hemoglobin synthesis. } \\
\text { neurotoxicity, osteoporosis, breaks blood-brain barrier, } \\
\text { decrease sperm count and motility }\end{array}$ & $\begin{array}{c}{[38-40,48,54} \\
59,60,67,73 \\
74]\end{array}$ \\
\hline Manganese & Drinking water, cosmetics & $\begin{array}{c}\text { Essential element, hemoglobin synthesis, gastrointestinal } \\
\text { tract, cells functions, , neurological disturbances, muscle } \\
\text { dysfunction, }\end{array}$ & {$[54,74]$} \\
\hline
\end{tabular}




\begin{tabular}{|c|c|c|c|}
\hline Metal & Source & Effect in humans & References \\
\hline Nickle & $\begin{array}{c}\text { Cosmetics, stainless steel, corrosion-resistant alloys, } \\
\text { desalination plant tubing, coins, armor plates and } \\
\text { burglar-proof vaults, }\end{array}$ & $\begin{array}{l}\text { Essential element, cancer, nervous system damage, lung, } \\
\text { cardiovascular system, liver, kidney toxicities, cellular } \\
\text { damage and reduction in cell growth, decrease body weight }\end{array}$ & {$[54,74]$} \\
\hline Mercury & $\begin{array}{l}\text { Volcanic eruption, rock weathering, Natural fires, } \\
\text { cosmetics, folk medicines, dental amalgams, vaccines, } \\
\text { mercury mining, fossil fuels, coal power plants, } \\
\text { municipal waste, cement production, batteries; } \\
\text { pesticides, paper industry, Cosmetics }\end{array}$ & $\begin{array}{l}\text { Non-essential element, DNA damage, carcinogen, } \\
\text { embryotoxic, joint disease, kidney, lung, abnormal circulatory } \\
\text { system, neurological disorders, physiologica stress, fetotoxic, } \\
\text { skin rashes, tiredness, central nervous system, mental } \\
\text { retardation, headaches, blindness, sperm damage, miscarriage, } \\
\text { calcium homeostasis, behavioral abnormalities, learning } \\
\text { disabilities, estrogen mimic, abortion, tremor }\end{array}$ & $\begin{array}{c}{[48,54,62-} \\
68]\end{array}$ \\
\hline Zinc & $\begin{array}{l}\text { Most abundant in earth crust, battery manufacturing, } \\
\text { roofing building construction, paints, cosmetics, } \\
\text { photocopier papers, wall papers, inks, rubber } \\
\text { production, metal plating, brass manufacture, plumbing, } \\
\text { refineries, cosmetics, textiles }\end{array}$ & $\begin{array}{l}\text { Essential element, DNA damage, carcinogen, hemotoxicity, } \\
\text { fatigue, decrease test and smell, skin sores, stomach cramps, } \\
\text { nausea and vomiting, respiratory diseases, eye irritation, } \\
\text { pancreatic damage, birth defects. }\end{array}$ & $\begin{array}{c}{[38,48,54,73,} \\
68]\end{array}$ \\
\hline
\end{tabular}

Many heavy metals are used in traditional and international cosmetic brands, such as eyeliners, eyeshadows, lipsticks and powders. Most women use cosmetics daily without being aware of their contents and the health effects. The traditional known brands such as henna and kohol eyeliner are very common in many nations in the Middle East, Africa and India. Al-Dayel et al. [54] analyzed twenty-seven heavy metals and related elements from nine traditional and international brands from Bahrain, Bulgaria, India, Mauritania, Morocco, Nigeria, Oman, Pakistan, Saudi Arabia, the United Arab Emirates, the United Kingdom and the United States. They reported that the cosmetics contained different concentrations of $\mathrm{Al}, \mathrm{Ag}, \mathrm{As}, \mathrm{B}, \mathrm{Ba}, \mathrm{Ca}, \mathrm{Cd}, \mathrm{Co}, \mathrm{Cr}, \mathrm{Cu}, \mathrm{Fe}, \mathrm{Hg}, \mathrm{K}, \mathrm{Li}, \mathrm{Mg}, \mathrm{Mn}, \mathrm{Na}, \mathrm{Ni}, \mathrm{Pb}, \mathrm{Rb}, \mathrm{Sb}, \mathrm{Se}, \mathrm{Sn}$, $\mathrm{Sr}, \mathrm{U}, \mathrm{V}$ and $\mathrm{Zn}$. Some with high concentrations of those element, suggesting that thorough investigation and evaluation of such products are needed for their safety.

Traditional remedies and medicines from China, India, Middle East, and Pakistan were also reported to contain heavy metals. In Oman and the United Arab Emirates, the traditional medicine "bint al dhahab" contained $\mathrm{Cd}, \mathrm{Pb}$ and $\mathrm{Sb}$ [55]. Some Asian herbal remedies were found to contain toxic heavy metals [56]. Saper et al. [57], reported that Ayurvedic herbal medicinal products contained $\mathrm{As}, \mathrm{Hg}, \mathrm{Pb}$ and that $\mathrm{Pb}$ was the main constituent of Indian traditional remedies. Most of herbal medicines are not regulated and are easily accessible to the public. On the other hand, in Pakistan, occurrence of $\mathrm{Pb}, \mathrm{Cd}, \mathrm{Cu}, \mathrm{Cr}, \mathrm{Co}, \mathrm{Fe}, \mathrm{Ni}$ and $\mathrm{Zn}$ contaminants due to environmental pollution was reported in herbal plants. These plants include Cuminum cyminum, Coriandrum sativum, Foeniculum vulgare, Glycyrrhiza glabra, Onosma bracteatum, Viola odorata, and Zingiber officinalis which is evident that a health risk is associated with the use of such herbal drugs [58].

Aluminum is commonly found in food and water. This element was reported in the brains of patients suffering with Alzheimer's [42, 44].

Arsenic is found naturally in inorganic and organic forms. Arsenic intoxication is most commonly reported in cases with much toxic inorganic form. Seafood, for example, contains the highest concentration of As in an organic form [40].

Chronic $\mathrm{Cd}$ toxicity is rare but fatal and has no metabolic benefit in humans and other animals. It is mainly found in a marine environment. When ingested it affects internal organs, including spleen, kidney, liver and pancreas, while mimicking the zinc function in metabolic processes [46]. It is also reported to be carcinogenic $[5,6]$.

Toxicity due to iron is most common, affecting melanin and causing grey or bronze skin color pigmentation, damaging the liver, causing heart failure and joint diseases [41, 45].

The most frequent toxic metal reported is lead exposure from painted items, water pipes, children toys and some cosmetic items, such as mascara eyeliners [40]. It is one of the non-essential elements with no role in human metabolism, with children being more affected than adults [59]. Lead replaces calcium in bones and weakens bone structure and replaces $\mathrm{Zn}$, blocking oxygen exchange in red blood cells. It is also interfering with some enzymes where magnesium is a co-factor affecting nucleotide synthesis [60].

The effects of mercury were reported by many researchers [61 - 65]. Sal̀'llsten et al. [66] reported that exhalation in low-level-mercury-exposed humans is treated with small doses of ethanol. 


\section{ROLE OF SEWAGE EFFLUENT POLLUTION IN ARID ZONE REGIONS}

Rainfall scarcity in arid zone region is a common problem. Many countries with seacoast depend on seawater desalination plants for household and industrial uses. The produced sewage effluents are treated and recycled. The reclaimed water is used in agriculture, industries and public gardens $[13,50]$. Some of the reclaimed water is disposed to sea or injected to aquifers [49]. However, aquifer recharging is an expensive process [76].

Oman and the rest of the Gulf Corporation Countries (GCC) are in the arid regions with severe lack of rain, depending mainly on desalinated water and recycling of sewage effluents [50]. Many studies in Oman have reported heavy metals in well water, soil, crops and marine habitats of fish and marine turtles $[15,50]$. Some industrial applications of heavy metals $(\mathrm{Y}, \mathrm{Yb}, \mathrm{Te}$ and $\mathrm{Zr}$ ) were detected in marine green turtle eggs (Chelonia mydas) at Ras AlHadd Turtle Reserve, Oman, suggesting that marine habitats are contaminated with industrial polluted effluents [14]. Treated sewage effluents were found to be the main source of such contamination. It is clearly indicated that the current technologies used in treating sewage effluents are not sufficient for removal of heavy metals and pathogenic microbes which are resistant to many antibiotics. The microbes were found to resist chlorination and were also found in well water, fish and marine turtles [14, 15 - 50]. For example, some researchers reported that microbes resistant to antibiotics are also resistant to heavy metals. Probably these microbes use the same mechanisms of resistance [77]. Such microbes were found in heavily polluted sewage effluents where they can be potentially used for bioremediation of heavy metals and solve the downsides of conventional methods which produce harmful secondary products.

Treatment of sewage effluent mainly relies on biological functions of microbes. Such microbes play an important role in bioremediation by breaking down toxic compounds under aerobic and anaerobic conditions where each microbial population plays a specific function. However, researchers reported that elimination of heavy metals from sewage effluent is inefficient $[15,73]$. Probably the existence and interaction of appropriate microbial population at appropriate environmental conditions could be a key. Hence, isolation and identification of the right microbes to remove heavy metal toxicity are highly essential [78].

\section{MICROBIAL BIOREMEDIATION}

Heavy metal pollution continues to be one of the most important global threats. Out of twenty classified toxic heavy metals, half of them are released at higher concentrations with high potential to human health and the environment [78]. One of the main sources of water pollution is the discharge of industrial contaminated sewage effluents with heavy metals, such as $\mathrm{Ag}, \mathrm{As}, \mathrm{Au}, \mathrm{Cd}, \mathrm{Co}, \mathrm{Cr}, \mathrm{Cu}, \mathrm{Hg}, \mathrm{Ni}, \mathrm{Pb}, \mathrm{Pd}, \mathrm{Pt}, \mathrm{Rd}, \mathrm{Sn}, \mathrm{Th}, \mathrm{U}$ and $\mathrm{Zn}$. Continuous discharge of heavy metals into the environment and their accumulation cause adverse effects on terrestrial and aquatic environments as well as the population.

Well established physicochemical technologies to remove heavy metals and other contaminants from sewage effluents already exist. These include cementation, ion exchange, precipitation, electrocoagulation and electrowinning $[73,78]$. However, these technologies are not cost-effective and needs skilled personnel for operation, generation of hazardous by-products and are inefficient for detoxifying low heavy metal concentrations [73, 79, 80]. Compared to conventional technologies, bioremediation is easy to operate, low metal concentration can be detoxified with high efficiency, self-sustaining system where the right microbes grow depending on the availability of the contaminant, harmful products are not produced and it can be operated in combination with conventional technologies [78, 79, 81]. The isolation and identification of heavy metal resistant bacteria in sewage effluent may contribute to efficient technologies to remove heavy metal pollutants from sewage effluents before being discharged to environment.

Microorganisms convert many toxic heavy metals through the process of metabolism into other non-toxic useful forms [82]. Microorganisms bioremediate heavy metals by several methods including bioleaching, enzyme-catalyzed transformation, biomineralization, biosorption and intracellular accumulation [83]. Most of heavy metal bioremediation occurs through the biosorption mechanisms [84]. However, ideal environmental conditions have to be met for the efficient bioremediation process.

In metal sulfide ores, ideal environmental conditions for maximum rates of bleaching at mining sites was reported at an optimum elevated temperature where high yields of metal extraction were achieved [85]. It was reported that the addition of appropriate nutrients enhances oxygen demand for Pseudomonas species and hence the active uptake of metals [86]. On the other hand, at optimum anaerobic conditions, Klebsiella pneumonia was reported to bioaccumulate high concentrations $(15 \mathrm{mM})$ of heavy metals [87].

Basha and Rajaganesh [73], reported that Bacillus licheniformis, Pseudomonas fluorescence, Salmonella typhi and 
Escherichia coli, isolated from textile industry effluents were used effectively to bioremediate zinc, lead, cadmium, other toxic chemicals. Both free or complex ionic forms of zinc, lead and cadmium are discharged by various industries, such as textile industries [88].

The main disadvantage of microbial bioremediation appropriate conditions to achieve maximum detoxification of pollutants $[78,86-88]$.

\section{CONCLUSION}

Heavy metals are found in the earth's crust. They cannot be degraded or destroyed. They enter the body via food, water and air. The majority of the metals are non-essential. Heavy metals can bioaccumulate gradually in the organism and stored in the body faster than they can be metabolized. Heavy metals can enter water such as rivers, lakes, seas and underground water. The most dangerous heavy metals in the environment are lead, cadmium and mercury. These can cause several serious diseases. Heavy metals can be found in wide environmental distribution such as soil, underground water, marine and fresh water habitats. Heavy metal detoxification in contaminated effluents is a global challenge. Current technologies are not efficient. Cheaper and efficient technologies are needed. Microbial bioremediation may be an alternative solution. However, further research is essential to understand microbial bioremediation of heavy metal pollutants before discharging contaminated effluents into the environment. International regulatory standards must be established to prevent the spread of non-essential metals in the environment such as arsenic, beryllium, cadmium, lead and mercury. The rest of the essential metals must also be regulated since an increase over the physiological limit can also be harmful. These regulations must be rigidly enforced.

\section{CONFILICT OF INTERST}

The authors confirm that this article content has no conflict of interest.

\section{ACKNOWLEDGEMENTS}

Declared none.

\section{REFERENCES}

[1] He Z, Shentu J, Yang X, Baligar VC, Zhang T, Stoffella PJ. Heavy metal contamination of soils: Sources, indicators, and assessment. J Envie Indicators 2015; 9: 17-8.

[2] Maier RM, Pepper IL, Gerba CP, Eds. Environmental Microbiology: Microorganisms and Metal Pollutants. San Diego, CA: Academic Press 2000; pp. 403-23.

[3] Kojadinovic J, Potier M, Le Corre M, Cosson RP, Bustamante P. Bioaccumulation of trace elements in pelagic fish from the Western Indian Ocean. Environ Pollut 2007; 146(2): 548-66. [http://dx.doi.org/10.1016/j.envpol.2006.07.015] [PMID: 17084003]

[4] Sinicropi MS, Amantea D, Caruso A, Saturnino C. Chemical and biological properties of toxic metals and use of chelating agents for the pharmacological treatment of metal poisoning. Arch Toxicol 2010; 84(7): 501-20. [http://dx.doi.org/10.1007/s00204-010-0544-6] [PMID: 20386880]

[5] Thévenod F, Lee WK. Toxicology of cadmium and its damage to mammalian organs. Met Ions Life Sci 2013; 11: 415-90. [http://dx.doi.org/10.1007/978-94-007-5179-8_14] [PMID: 23430781]

[6] BBC. China smog sparks red alerts in 10 cities. Available at: http://www.bbc.com/news/world-asia-china-35173709. [Accessed on: 8th May, 2016]. 2016

[7] Jia H. China gets tough with polluters. Royal Society of Chemistry. UK. 2016. Available at: http://www.rsc.org/chemistryworld/2014/06/ china-gets-tough-polluters-remediation. [Accessed on: 8th May, 2016].

[8] Mahmoud IY, Al-Bahry SN, Al-Musharafi SK. Fresh water habitat pollution by treated sewage effluent in relation to multiple-antibioticresistant bacteria. APCBEES Procedia 2013; 5: 363-7. [http://dx.doi.org/10.1016/j.apcbee.2013.05.062]

[9] Svobodová Z, Gelnarová J, Justýn J, Krupauer V, Máchová J, Simanov 1. Toxikologie vodních živočichů. SZN Praha 1987.

[10] Al-Musharafi SK, Mahmoud IY, Al-Bahry SN. Environmental contamination by industrial effluents and sludge relative to heavy metals. J Geos Envir Prot 2014; 2: 14-8.

[http://dx.doi.org/10.4236/gep.2014.22003]

[11] Al-Bahry SN, Mahmoud I, Al-Rawahi S, Paulson J. Egg contamination as an indicator of environmental health. New York: Nova Science Publisher Inc. 2011.

[12] Al-Musharafi SK, Mahmoud IY, Al-Bahry SN. Contamination of marine fish by heavy metals from coastal sewage treated effluent runoff. In: The Third Asian Conference on Sustainability, Energy and the Environment. acsee 2013. The International Academic Forum (IAFOR).; 
Osaka, Japan. 2013; pp. 100-7.

[13] Al-Musharafi SK, Mahmoud IY, Al-Bahry SN. Heavy metals infiltration from sewage treated effluent into soil and tomato plants. IPCBEE 2013; 50: 16-25. Available at: http://www.academia.edu/download/39127195/02e7e5367bc29700c8000000.pdf

[14] Al-Musharafi SK. Biotechnology and Conservation of Species from Arid Regions. Analysis of heavy metal in eggshells of green turtles by scanning electron microscopy and x-ray microanalysis. New York: Nova Science Publisher, Inc. 2014; pp. 137-44. Available at: https://scholar.google.com/scholar?oi=bibs\&cluster=5651951713140915359\&btnI=1\&hl=en

[15] Holm PB, Peter A, Segner H. Decline of fish catch in Switzerland. Aquat Sci 2002; 64: 36-54. [http://dx.doi.org/10.1007/s00027-002-8053-1]

[16] Harper ER, St Leger JA, Westberg JA, et al. Tissue heavy metal concentrations of stranded California sea lions (Zalophus californianus) in Southern California. Environ Pollut 2007; 147(3): 677-82. [http://dx.doi.org/10.1016/j.envpol.2006.09.013] [PMID: 17116350]

[17] Jeffree RA, Warnau M, Oberhansli F, Teyssie JL. Bioaccumulation of heavy metals and radionuclides from seawater by encased embryos of the spotted dogfish Scyliorhinus canicula. Mar Pollut Bull 2006; 52(10): 1278-86. [http://dx.doi.org/10.1016/j.marpolbul.2006.03.015] [PMID: 16797035]

[18] Kannan K, Agusa T, Perrotta E, Thomas NJ, Tanabe S. Comparison of trace element concentrations in livers of diseased, emaciated and nondiseased southern sea otters from the California coast. Chemosphere 2006; 65(11): 2160-7. [http://dx.doi.org/10.1016/j.chemosphere.2006.06.003] [PMID: 16846630]

[19] Mapanda F, Mangwayana EN, Giller KE, Nyamangara J. Uptake of Heavy metals by vegetables irrigated using wastewater and the subsequent risks in Harare, Zimbabwe. Phys Chem Earth 2007; 32: 1399-405. [http://dx.doi.org/10.1016/j.pce.2007.07.046]

[20] Storelli MM, Barone G, Storelli A, Marcotrigiano GO. Total and subcellular distribution of trace elements (Cd, Cu and $\mathrm{Zn})$ in the liver and kidney of green turtles (Chelonia mydas) from the Mediterranean Sea. Chemosphere 2008; 70(5): 908-13. [http://dx.doi.org/10.1016/j.chemosphere.2007.06.069] [PMID: 17707456]

[21] Zauke GP, Clason B, Savinov VM, Savinova T. Heavy metals of inshore benthic invertebrates from the Barents Sea. Sci Total Environ 2003; 306(1-3): 99-110. [http://dx.doi.org/10.1016/S0048-9697(02)00487-4] [PMID: 12699921]

[22] Talavera-Saenz A, Gardner SC, Riosmena Rodriquez R, Acosta Vargas B. Metal profiles used as environmental markers of green turtle (Chelonia mydas) foraging resources. Sci Total Environ 2007; 373(1): 94-102. [http://dx.doi.org/10.1016/j.scitotenv.2006.10.012] [PMID: 17188334]

[23] de Mora S, Fowler SW, Wyse E, Azemard S. Distribution of heavy metals in marine bivalves, fish and coastal sediments in the Gulf and Gulf of Oman. Mar Pollut Bull 2004; 49(5-6): 410-24. [http://dx.doi.org/10.1016/j.marpolbul.2004.02.029] [PMID: 15325209]

[24] Nelson SA. Mineral Resources. 2016. Available at: http://www.tulane.edu/ sanelson/eens1110/minresources.htm. [Accessed on: $8^{\text {th }}$ May, 2016].

[25] Bloodworth A. Resources: Track flows to manage technology-metal supply. Nature 2014; 505(7481): 19-20. [http://dx.doi.org/10.1038/505019a] [PMID: 24380940]

[26] Organization for Economic Co-operation and Development (OECD). Rising air pollution-related deaths taking heavy toll on society, OECD says 2014.

[27] The Global Burden of Disease. The Global Burden of Disease from Motorized Road Transport Transport for Health. USA: Institute for Health Metrics and Evaluation/The World Bank 2014.

[28] Energyskeptic. Metal recycling limited and not even possible in some cases. 2016. Available at: http://energyskeptic.com/2013/ metalrecycle-limited-by-many-factors/. [Accessed on: 8th May].

[29] FF Conserve Energy Future. Metal recycling 2016. Available at: http://www.conserve-energy- future.com/RecyclingMetal.php. [Accessed on: $8^{\text {th }}$ May].

[30] Canadian Ministry of the Environment (CME). Soil, Ground Water and Sediment Standards for Use under Part XV.1 of the Environmental Protection Act, 2011.

[31] Environment Protection Authority of Australia (EPAA). 2012. Classification and management of contaminated soil for disposal. Information Bulletin 105. Hobart, TAS 7001 Australia. 2009.

[32] European Environmental Agency (EEA). Progress in management of contaminated sites (CSI 015/LSI 003) 2016. Available at: http://www.eea.europa.eu/data-and-maps/indicators. [Accessed on: $8^{\text {th }}$ May, 2016].

[33] Environmental Protection Ministry of China (EPMC). Standards of soil environmental quality of agricultural land. Huangbanhang 69: Office of Environmental Protection Ministry of China, Beijing, China. 2015.

[34] New Zealand Ministry for the Environment (NZME). Users' Guide: National Environmental Standard for Assessing and Managing Contaminants in Soil to Protect Human Health Wellington: Ministry for the Environment 2012. Available from: http://www.esdat.net.

[35] Tanzania Minister of State (TMS). Tanzania Minister of State (TMS). The environmental management (soil quality standards) regulations, Vice President's Office - Environment 2007. 
[36] United States Environmental Protection Agency (US EPA). Supplemental guidance for developing soil screening levels for superfund sites. Office of Solid Waste and Emergency Response, Washington, DC 2016. Available at : www.epa.gov/superfund/health/conmedia/ soil/index.htm. [Accessed on: $8^{\text {th }}$ May]

[37] Victor B. Heavy metal contamination of global environment. 2016. Available at: http://www.slideshare.net/biotechvictor1950/ heavy-metalcontamination-of-global-environment. [Accessed on: $8^{\text {th }}$ May].

[38] Be M. A guide to heavy metals and their health effects. 2016. Available at: http://wakeup-world.com/2015/02/07/ a-guide-to-heavy-metalsand-their-health-effects/wuw_pag.

[39] Bronstein AC, Spyker DA, Cantilena LR Jr, Rumack BH, Dart RC. 2011 annual report of the american association of poison control centers' national poison data system (NPDS): $29^{\text {th }}$ annual report. Clin Toxicol (Phila) 2012; 50(10): 911-1164. [http://dx.doi.org/10.3109/15563650.2012.746424] [PMID: 23272763]

[40] Ibrahim D, Froberg B, Wolf A, Rusyniak DE. Heavy metal poisoning: clinical presentations and pathophysiology. Clin Lab Med 2006; 26(1): 67-97, viii.

[http://dx.doi.org/10.1016/j.cll.2006.02.003] [PMID: 16567226]

[41] Lemire J, Appanna VD. Aluminum toxicity and astrocyte dysfunction: a metabolic link to neurological disorders. J Inorg Biochem 2011; 105(11): 1513-7. [http://dx.doi.org/10.1016/j.jinorgbio.2011.07.001] [PMID: 22099161]

[42] Reddy CC, Scholz RW, Massaro EJ. Cadmium, methylmercury, mercury, and lead inhibition of calf liver glutathione S-transferase exhibiting selenium-independent glutathione peroxidase activity. Toxicol Appl Pharmacol 1981; 61(3): 460-8. [http://dx.doi.org/10.1016/0041-008X(81)90369-0] [PMID: 7330884]

[43] Percy ME, Kruck TP, Pogue AI, Lukiw WJ. Towards the prevention of potential aluminum toxic effects and an effective treatment for Alzheimer's disease. J Inorg Biochem 2011; 105(11): 1505-12. [http://dx.doi.org/10.1016/j.jinorgbio.2011.08.001] [PMID: 22099160]

[44] Siddique A, Kowdley KV. Review article: the iron overload syndromes. Aliment Pharmacol Ther 2012; 35(8): 876-93. [http://dx.doi.org/10.1111/j.1365-2036.2012.05051.x] [PMID: 22385471]

[45] Sigel A, Sigel H, Sigel R. Cadmium: from toxicity to essentiality. In: Metal ions in life sciences. Germany: Springer 2013 ; p.11.

[46] Thévenod F, Lee WK. Toxicology of cadmium and its damage to mammalian organs. Met Ions Life Sci 2013; 11: 415-90. [http://dx.doi.org/10.1007/978-94-007-5179-8_14] [PMID: 23430781]

[47] Wang W, Mao H, Ma D, Yang W. Characteristics, functions, and applications of metallothionein in aquatic vertebrates. Front Mar Sci 2014; 1: 1-12. [http://dx.doi.org/10.3389/fmars.2014.00034]

[48] Al-Bahry SN, Mahmoud IY, Al-Belushi KI, Elshafie AE, Al-Harthy A, Bakheit CK. Coastal sewage discharge and its impact on fish with reference to antibiotic resistant enteric bacteria and enteric pathogens as bio-indicators of pollution. Chemosphere 2009; 77(11): 1534-9. [http://dx.doi.org/10.1016/j.chemosphere.2009.09.052] [PMID: 19853276]

[49] Al-Bahry SN, Mahmoud IY, Al-Musharafi SK, Al-Gharaibi IS, Al-Harthy NK, Al-Zadjali HA. Microbial and chemical pollution of waterwells relative to sewage effluents in Oman. IJSEE 2014; 1: 35-56. Available at: http://iafor.org/archives/journals/sustain-journal/ IJSEEv1n1a4.pdf

[50] European Environmental Agency(EAA). Heavy metals emission intensity of the metal industry. Available at: http://www.eea.europa.eu/dataand-maps/daviz/heavy-metals-emission-intensity-of-3\#tab-chart_1 2016. [(Accessed on: 8th May)]

[51] NRDC. Know Where It's Coming From. Available at: http://www.nrdc.org/health/effects/mercury/sources.asp. 2016. [Accessed on: $8^{\text {th }}$ May].

[52] Ayres RU. Toxic heavy metals: materials cycle optimization. Proc Natl Acad Sci USA 1992; 89(3): 815-20. [http://dx.doi.org/10.1073/pnas.89.3.815] [PMID: 11607259]

[53] Al-Dayel O, Hefne J, Al-Ajyan T. Human exposure to heavy metals from cosmetics. Orient J Chem 2011; 27: 01-11.

[54] Worthing MA, Sutherland HH, al-Riyami K. New information on the composition of bint al Dhahab, a mixed lead monoxide used as a traditional medicine in Oman and the United Arab Emirates. J Trop Pediatr 1995; 41(4): 246-7. [http://dx.doi.org/10.1093/tropej/41.4.246] [PMID: 7563280]

[55] Ernst E. Toxic heavy metals and undeclared drugs in Asian herbal medicines. Trends Pharmacol Sci 2002; 23(3): 136-9. [http://dx.doi.org/10.1016/S0165-6147(00)01972-6] [PMID: 11879681]

[56] Saper RB, Kales SN, Paquin J, et al. Heavy metal content of ayurvedic herbal medicine products. JAMA 2004; $292(23): 2868-73$. [http://dx.doi.org/10.1001/jama.292.23.2868] [PMID: 15598918]

[57] Hina B, Rizwani GH, Naseem S. Determination of toxic metals in some herbal drugs through atomic absorption spectroscopy. Pak J Pharm Sci $2011 ; 24(3): 353-8$. [PMID: 21715269]

[58] Abelsohn AR, Sanborn M. Lead and children: clinical management for family physicians. Can Fam Physician 2010; 56(6): 531-5. [PMID: 20547517]

[59] Kirberger M, Wong HC, Jiang J, Yang JJ. Metal toxicity and opportunistic binding of $\mathrm{Pb}\left(2^{+}\right)$in proteins. J Inorg Biochem 2013; 125 : 40-9. 
[http://dx.doi.org/10.1016/j.jinorgbio.2013.04.002] [PMID: 23692958]

[60] ATSDR. Mercury ToxFAQ. 2016 [Available at: http://www.atsdr.cdc.gov/toxfaqs/tfacts46_metallic_mercury.pdf. Accessed on: $8^{\text {th }}$ May];

[61] Caravati EM, Erdman AR, Christianson G, et al. Elemental mercury exposure: an evidence-based consensus guideline for out-of-hospital management. Clin Toxicol (Phila) 2008; 46(1): 1-21. [http://dx.doi.org/10.1080/15563650701664731] [PMID: 18167033]

[62] Gallagher CM, Meliker JR. Mercury and thyroid autoantibodies in U.S. women, NHANES 2007-2008. Environ Int 2012; 40: 39-43. [http://dx.doi.org/10.1016/j.envint.2011.11.014] [PMID: 22280926]

[63] Houston MC. Role of mercury toxicity in hypertension, cardiovascular disease, and stroke. J Clin Hypertens (Greenwich) 2011; 13(8): 621-7. [http://dx.doi.org/10.1111/j.1751-7176.2011.00489.x] [PMID: 21806773]

[64] Yang J, Jiang Z, Wang Y, Qureshi IA, Wu XD. Maternal-fetal transfer of metallic mercury via the placenta and milk. Ann Clin Lab Sci 1997; 27(2): 135-41.

[PMID: 9098513]

[65] Sällsten G, Kreku S, Unosson H. A small dose of ethanol increases the exhalation of mercury in low-level-exposed humans. J Toxicol Environ Health A 2000; 60(2): 89-100. [http://dx.doi.org/10.1080/009841000156510] [PMID: 10872631]

[66] Hunt A. Policy interventions to address health impacts associated with air pollution, unsafe water supply and sanitation, and hazardous chemicals 2011.

[67] Sing R. Heavy metals and living systems: An overview. IJP 2011; 43: 246-53.

[68] Cooper RG, Harrison AP. The uses and adverse effects of beryllium on health. Indian J Occup Environ Med 2009; 13(2): 65-76. [http://dx.doi.org/10.4103/0019-5278.55122] [PMID: 20386622]

[69] Department of Labor USA. Occupational Safety \& Health Administration. Safety and Health Topics 2016. Available at: https://www.osha.gov/ SLTC/beryllium/. [Accessed on: $8^{\text {th }}$ May].

[70] Dudek W, Walusiak J, Wittczak T. Beryllium-underestimated occupational health hazard in Poland. Med Pr 2001; 52(6): 471-8. [PMID: 11928678]

[71] Newman LS. Metals that cause sarcoidosis. Semin Respir Infect 1998; 13(3): 212-20. [PMID: 9764952]

[72] Basha AS, Rajaganesh K. Microbial bioremediation of heavy metals from textile industry dye effluents using isolated bacterial strains. IJCMAS 2014; 5: 785-94. Available at: http://www.ijcmas.com/vol-3-5/S.Ameer\%20Basha\%20and\%20K.Rajaganesh.pdf

[73] Gautam RK, Sharma SK, Mahiya S, Chattopadhyaya MC. Contamination of heavy metals in aquatic media: transport, toxicity and technologies for remediation. In: Heavy Metals in Water: Presence, Removal and Safety. Royal Society of Chemistry 2014; pp. 1-24. [http://dx.doi.org/10.1039/9781782620174-00001]

[74] Gault N, Sandre C, Poncy JL, Moulin C, Lefaix JL, Bresson C. Cobalt toxicity: chemical and radiological combined effects on HaCaT keratinocyte cell line. Toxicol In Vitro 2010; 24(1): 92-8. [http://dx.doi.org/10.1016/j.tiv.2009.08.027] [PMID: 19735721]

[75] Save Palo Alto's Groundwater. Proposed updates to city of Palo Alto policies pertaining to the pumping of groundwater for basement construction. 2016. Available at: http://savepaloaltosgroundwater.org/files/Save_Palo_Altos_Groundwater_White_paper.pdf. [Accessed on: $8^{\text {th }}$ May]

[76] Hölzel CS, Müller C, Harms KS, et al. Heavy metals in liquid pig manure in light of bacterial antimicrobial resistance. Environ Res 2012; 113: 21-7. [http://dx.doi.org/10.1016/j.envres.2012.01.002] [PMID: 22280821]

[77] Akpor OB, Muchie M. Remediation of heavy metals in drinking water and wastewater treatment systems: Processes and applications. Int J Phys Sci 2010; 5: 1807-17.

[78] Vargas García M, Suárez Estrella F, López López M, Guisado Ubeda G, Moreno Casco J. Bioremediation of heavy metals with microbial isolates. In: $14^{\text {th }}$ Ramiran International Conference of the Fao Escorena Network on the Recycling of Agricultural, Municipal and Industrial Residues in Agriculture; $13^{\text {th }}$ to the $15^{\text {th }}$ September; Lisboa, Portugal. 2010.

[79] Wang J, Chen C. Biosorbents for heavy metals removal and their future. Biotechnol Adv 2009; 27(2): 195-226. [http://dx.doi.org/10.1016/j.biotechadv.2008.11.002] [PMID: 19103274]

[80] De J, Ramaiah N, Vardanyan L. Detoxification of toxic heavy metals by marine bacteria highly resistant to mercury. Mar Biotechnol (NY) 2008; 10(4): 471-7.

[http://dx.doi.org/10.1007/s10126-008-9083-z] [PMID: 18288535]

[81] Gupta AK, Yunus M, Pandey P. Bioremediation: ecotechnology for the present century. Inter Soc Environ Botanists Environnews 2003; 9(2) Available from: http://isebindia.com/01_04/03-04-2.html.

[82] Lloyd JR. Bioremediation of metals: The application of microorganisms that make and break minerals. Microbiol Today 2002; 29 : 67-9.

[83] Haferburg G, Kothe E. Microbes and metals: interactions in the environment. J Basic Microbiol 2007; 47(6): 453-67. [http://dx.doi.org/10.1002/jobm.200700275] [PMID: 18072246] 
[84] Martín-González A, Díaz S, Borniquel S, Gallego A, Gutiérrez JC. Cytotoxicity and bioaccumulation of heavy metals by ciliated protozoa isolated from urban wastewater treatment plants. Res Microbiol 2006; 157(2): 108-18. [http://dx.doi.org/10.1016/j.resmic.2005.06.005] [PMID: 16129584]

[85] Hussein H, Farag S, Kandil K, Moawad H. Resistance and uptake of heavy metals by Pseudomonads. Process Biochem 2005 ; 40 : 955-61. [http://dx.doi.org/10.1016/j.procbio.2004.04.001]

[86] Sharma PK, Balkwill DL, Frenkel A, Vairavamurthy MA. A new Klebsiella planticola strain (Cd-1) grows anaerobically at high cadmium concentrations and precipitates cadmium sulfide. Appl Environ Microbiol 2000; 66(7): 3083-7. [http://dx.doi.org/10.1128/AEM.66.7.3083-3087.2000] [PMID: 10877810]

[87] Hill WE, Perkins S, Sandlin GS. Removal and speciation of transition metal ions textile dyeing wastewaters. Text Chem Color 1993; $25: 26-7$.

[88] Gadd GM. Metals, minerals and microbes: geomicrobiology and bioremediation. Microbiology 2010; 156(Pt 3): 609-43. [http://dx.doi.org/10.1099/mic.0.037143-0] [PMID: 20019082]

(C) Salma K. Al-Musharafi; Licensee Bentham Open.

This is an open access article licensed under the terms of the Creative Commons Attribution-Non-Commercial 4.0 International Public License (CC BY-NC 4.0) (https://creativecommons.org/licenses/by-nc/4.0/legalcode), which permits unrestricted, non-commercial use, distribution and reproduction in any medium, provided the work is properly cited. 